\begin{tabular}{|l|l|l||}
\hline \multicolumn{2}{|c|}{ PublisherInfo } \\
\hline \hline PublisherName & $:$ & BioMed Central \\
\hline \hline PublisherLocation & $:$ & London \\
\hline \hline PublisherImprintName & $:$ & BioMed Central \\
\hline \hline
\end{tabular}

\title{
Small RNAs in yeast
}

\begin{tabular}{|l|l|l||}
\hline \multicolumn{2}{|c|}{ ArticleInfo } \\
\hline \hline ArticleID & $:$ & 4560 \\
\hline \hline ArticleDOI & $:$ & $10.1186 /$ gb-spotlight-20020822-01 \\
\hline \hline ArticleCitationID & $:$ & spotlight-20020822-01 \\
\hline \hline ArticleSequenceNumber & $:$ & 226 \\
\hline \hline ArticleCategory & $:$ & Research news \\
\hline ArticleFirstPage & $:$ & 1 \\
\hline \hline ArticleLastPage & $:$ & 2 \\
\hline \hline & & RegistrationDate : 2002-8-22 \\
\hline ArticleHistory & $:$ & OnlineDate \\
\hline \hline ArticleCopyright & $:$ & BioMed Central Ltd2002-8-22 \\
\hline \hline ArticleGrants & $:$ & \\
\hline \hline ArticleContext & $:$ & 130593311 \\
\hline \hline
\end{tabular}




\section{Jonathan B Weitzman}

Email: jonathanweitzman@hotmail.com

Small interfering RNAs (siRNAs) are non-coding RNAs, around 22 nucleotides long, that regulate gene expression. The Dicer and Argonaute proteins are necessary for the processing of siRNAs from longer double-stranded RNA. The presence of Dicer and Argonaute homologs in the Schizosaccharomyces pombe genome prompted Reinhart and Bartel to isolate small RNAs from fission yeast (Sciencexpress, 22 August 2002, DOI:10.1126/science.1077183). They used a cloning method designed to isolate Dicer cleavage products, and found that one third of the sequenced clones matched centromeric repeat sequences in the yeast genome. Reinhart and Bartel suggest that these siRNAs, which they call heterochormatic siRNAs, are generated by Dicer-mediated processing of dsRNA generated from both DNA strands of the repeat region. As dicer mutations affect the methylation of histone $\mathrm{H} 3$ at the centromere in S. pombe, Reinhart and Bartel propose that these small RNAs may play a role in histone modification and epigenetic regulation.

\section{References}

1. RNAi: nature abhors a double-strand.

2. Sciencexpress, [http://www.sciencexpress.org]

3. An abundant class of tiny RNAs with probable regulatory roles in Caenorhabditis elegans. 